\title{
Fiscal Policy and Economic Growth in Tunisia
}

\section{Chokri Terzi ${ }^{*}$ and El Ammari Anis ${ }^{2}$}

${ }^{1}$ Department of Quantitative Method, Higher Institute of Management, University of Gabès, Tunisia

${ }^{2}$ Department of Finance, Faculty of Economic Sciences and Management of Mahdia, University of Monastir, Tunisia

Fiscal system must be capable to find the resources necessary for the good functioning of the state with developing economic growth. Fiscal policy can be used to regulate economic activity by modifying the fiscal effort required of taxpayers or to take the form of fiscal incentives to reduce the tax burden in order to boost consumption, investment and employment. Socially, taxation is considerate as an instrument for redistributing incomes in the direction of greater equity.

The analysis which focuses on theoretical relationship between taxation and growth should take in account that growth is not the unique objective of the fiscal policy. So, the optimal tax rate for the growth could not be the same as the one who would maximize the wellbeing of the population. Recent research concludes that fiscal policy is not economically neutral because high tax rates hold back economic growth and reach consensus on the macroeconomic effects of taxation. This finding is closely linked to the emergence since 1970 of a supply theory based on the fact that " too much tax kills tax " [1]. This idea was illustrated by an inverted U-shaped curve indicating that there is a taxation optimal level for a given economy. Therefore, policy makers and economists have warned that excessive taxation is costly for the government in terms of growth and tax revenues. High tax rates result in tax avoidance and evasion. More taxpayers are likely to defraud or to avoid paying taxes, lower tax revenue collected will be higher and will be the financial costs needed to comply with tax rules. On the other hand, lower taxes reduce the fraud likelihood and tax evasion.

Empirical works that attempt to analyze the link between taxes and economic growth shows that results depend on numerous factors and differs from country to country. A variety of studies claim that raising consumption taxes while at the same time lowering taxes on labor and capital can stimulate the economy's growth forces. At the same time, other studies note that tax burden and tax structure would have different impacts on economic activity for different countries and periods and under varying circumstances. Schneider and Rowley have shown that raising the tax burden could lead to multiple detours borrowed to avoid taxes through hesitation and the appearance of the underground economy [2]. Using panel regression method on the OECD countries for the period of 2000-2011, Macek deduced that corporate taxation followed by personal income taxes and social security contribution are the most harmful for economic growth [3]. Several studies have indicated mixed impacts of tax on economic growth. The study of Ogundajo and Onakoya investigated the impact of taxation on economic growth in Africa from 2004 to 2013 [4]. Findings indicated that tax revenue is positively related to GDP and promotes Economic Growth in Africa. High and weak levels of taxation are favorable to economic growth as upheld by the economic effect of Ibn Khaldun's theory on taxation, which approves the positive impact that lower tax rate have on work, output and economic performance.

\section{References}

1. Laffer AB (1981) Supply-Side Economics. Financial Analysts Journal 37: 29-44.

2. Schneider F, Rowley C (2008) Readings in Public Choice and Constitutional Political Economy. Shadow Economy 28: 512-532.

3. Macek R (2014) The Impact of Taxation on Economic Growth: Case Study of OECD Countries. Review of Economic Perspectives 14: 309-328.

4. Ogundajo G, Onakoya $A B O$ (2017) Taxation revenue and economic growth in Africa. Journal of Accounting and Taxation 9: 11-22.
*Corresponding author: Chokri Terzi, Department of Quantitative Method, Higher Institute of Management, University of Gabès, Tunisia, Tel: 75276090; E-mail: terisig5@yahoo.fr

Received March 16, 2018; Accepted March 22, 2018; Published March 30, 2018

Citation: Terzi C, Anis EA (2018) Fiscal Policy and Economic Growth in Tunisia. J Bus Fin Aff 7: 325. doi: 10.4172/2167-0234.1000325

Copyright: ( $\odot 2018$ Terzi C, et al. This is an open-access article distributed under the terms of the Creative Commons Attribution License, which permits unrestricted use, distribution, and reproduction in any medium, provided the original author and source are credited. 